\title{
Varicella Zoster Virus Myelitis in Two Elderly Patients: Diagnostic Value of Nested Polymerase Chain Reaction Assay and Antibody Index for Cerebrospinal Fluid Specimens
}

\author{
Teruyuki Takahashi ${ }^{a} \quad$ Masato Tamura ${ }^{a, d}$ Kenji Miki ${ }^{a, d}$ \\ Mai Yamaguchi ${ }^{a, d} \quad$ Akira Kanno $^{a, d}$ Satoshi Nunomura ${ }^{c}$ Chisei $\mathrm{Ra}^{c}$ \\ Takashi Tamiyab $^{\text {Satoshi Kamei }}{ }^{d}$ Toshiaki Takasu $^{a, d}$ \\ Departments of ${ }^{a}$ Neurology and ${ }^{b}$ Psychology, Nagaoka-Nishi Hospital, Nagaoka, and \\ Divisions of ${ }^{c}$ Molecular Cell Immunology and Allergology, and ${ }^{\mathrm{d}}$ Neurology, Department of \\ Medicine, Nihon University School of Medicine, Tokyo, Japan
}

\section{Key Words}

Varicella zoster virus · Myelitis · Enzyme immunoassay · Antibody index · Nested polymerase chain reaction assay

\begin{abstract}
Background: Myelitis is one of the rarest neurological complications of the varicella zoster virus (VZV) infection. Focal muscle weakness with or without sensory disturbance occurs in approximately $5 \%$ of the cases after acute VZV infection, with complete recovery in $50-70 \%$. Case Presentation: This report describes two rare cases of elderly patients with VZV myelitis secondary to dermatomal zoster rash. Patient 1 was a 79-year-old woman who developed paraplegia, numbness and decreased sensation in the left arm and below thoracic (Th)-10 after sacral zoster. Spinal cord MRI showed a high-signal-intensity lesion at the cervical spinal nerve 2 on a $T_{2}$-weighted image. Patient 2 was a 73-year-old man who developed right flaccid leg weakness and urinary retention after right dorsal Th 5-8 zoster. Spinal cord MRI showed a high-signal-intensity lesion at Th 3-4 on a $\mathrm{T}_{2}$-weighted image. In both cases, although the conventional single polymerase chain reaction (PCR) assays all showed negative results, the original nested PCR assay detected VZV DNA in the cerebrospinal fluid (CSF) specimen collected on admission. In addition, the anti-VZV IgG antibody by enzyme immunoassay and antibody index were elevated in the CSF specimens during the clinical courses of both patients. On the basis of these findings, both patients were diagnosed with
\end{abstract}

Teruyuki Takahashi, MD

Department of Neurology

Nagaoka-Nishi Hospital, Mitsugohya-machi 371-1

Nagaoka City, Niigata 940-2081 (Japan)

E-Mailnrd27501@nifty.com 
VZV myelitis and were treated with high-dose acyclovir and corticosteroid. This combined treatment was appropriate and effective for the improvement of their functional outcomes. Conclusion: The detection of VZV DNA in CSF by nested PCR assay and the evaluation of the antibody index to VZV had significant diagnostic value.

\section{Background}

Myelitis is one of the rarest neurological complications of the varicella zoster virus (VZV) infection [1-4]. Focal muscle weakness, called zoster paresis, with or without sensory disturbance, occurs in approximately $5 \%$ of the cases after acute VZV infection, with complete recovery in $50-70 \%$ and approximately $15 \%$ who do not experience any improvement. In addition, the immune setting of the patient affects the clinical presentation of VZV-related neurological complications [1-4]. At present, cerebrospinal fluid (CSF) analysis is a key tool in the diagnosis of the central nervous system (CNS) infection with VZV [3-9]. The detection of intrathecal synthesis of anti-VZV-specific antibodies by enzyme immunoassay (EIA) and the amplification of VZV DNA in CSF by polymerase chain reaction (PCR) assay are the most reliable methods of establishing a diagnosis of VZV infection in the CNS [3-9].

This report describes two elderly patients with VZV myelitis in whom both VZV DNA and anti-VZV antibody were detected in CSF during the disease, and whose disease improved by combined treatment with acyclovir and corticosteroid. In addition, the diagnostic value and clinical usefulness of the antibody index to VZV and nested PCR assay are discussed.

\section{Methods}

\section{CSF Collection Procedure}

CSF specimens of approximately 3-4 ml were collected by standard lumbar puncture. These specimens were divided into 3 or 4 aliquots for use in each examination. One aliquot was transferred to a commercial laboratory under refrigeration (at $4^{\circ} \mathrm{C}$ ) to perform EIA or conventional single PCR assay. Another aliquot was stored at $-20^{\circ} \mathrm{C}$ until use for original nested PCR assay.

\section{Enzyme Immunoassay}

Specific IgG and IgM antibodies to VZV, herpes simplex virus type-1 (HSV-1) and cytomegalovirus (CMV) in clinical specimens (serum and CSF) were quantitatively detected by EIA [3-9]. The respective EIA values were determined according to a previously reported protocol [10], with the work outsourced to a major commercial laboratory (SRL Inc., Tokyo, Japan).

The evaluation of the antibody index provides evidence of the intrathecal synthesis of anti-virus antibodies [11]. The antibody index is expressed as follows: (CSF antibody titer (EIA value)/serum antibody titer (EIA value))/(CSF IgG (mg/dl)/serum IgG (mg/dl)) [10, 11]. This ratio being superior to 1.5 or 2.0 suggests antibody production in the CNS $[10,11]$. 
Takahashi et al.: Varicella Zoster Virus Myelitis in Two Elderly Patients

\section{PCR Assays}

Clinical Routine Single-PCR Assays for 3 Types of Viral DNA

In this study, all of the routine clinical single-PCR assays for VZV, HSV-1 and CMV DNA in CSF specimens were outsourced to a major commercial laboratory (SRL Inc., Tokyo, Japan).

Original Nested PCR Assay for VZV DNA

The DNA specimens including VZV DNA were extracted and purified from $250 \mu \mathrm{CSF}$ aliquots by a previously reported conventional phenol-chloroform method and ethanol precipitation with a high-molecular-weight carrier, Ethachinmate ${ }^{\circledR}$ (Nippon Gene, Tokyo, Japan), as a coprecipitating agent for the nucleotides $[12,13]$.

For use in the two consecutive PCR amplification steps of the nested PCR assay, two pairs of the outer forward (WZ-F1) and reverse (WZ-R1) primers as well as the inner forward (WZ-F2) and reverse (WZ-R2) primers that were specific to the open reading frame (ORF) 29 in the VZV gene [GenBank accession no. NC_001348.1 (X04370)] [14] were prepared. The sequences of these primers are shown in table 1. In the first-step (single) PCR, $2 \mu \mathrm{l}$ of the extracted DNA specimen as a template were amplified using each of the outer primers, WZ-F1 and WZ-R1. In the second-step (nested) PCR, $2 \mu$ l of the single-PCR product as a template were amplified using each of the inner primers, WZ-F2 and WZ-R2. All PCR procedures followed the protocols shown in table 2, using GeneAmp PCR system 9700 (Applied Biosystems, Foster City, Calif., USA). The PCR products were analyzed using the Agilent 2100 Bioanalyzer System ${ }^{\mathrm{TM}}$ (Agilent Technologies, Waldbronn, Germany). The presence of a 172 base-pair (bp) band for single PCR and an 88-bp band for nested PCR indicated successful amplification.

\section{Case Presentation}

\section{Patient 1}

On February 26, 2010, a previously healthy and HIV-negative 79-year-old woman developed mild fever and focal skin rash with pain in her gluteal region. Moreover, on March 9, she developed gradually progressive gait disturbance. On admission, on March 11, her temperature was $37.6^{\circ} \mathrm{C}$ and focal zoster rash was distributed in the sacral 2-3 gluteal region. Upon neurological examination, she demonstrated mild right hand weakness, moderate left dominant paraplegia with bilateral hyporeflexia of the lower limbs, and numbness with decreased sensation in the left arm and bilateral trunk and legs below thoracic (Th)-10. Both planter responses were absent. Spinal cord MRI showed a highsignal-intensity lesion at the cervical spinal nerve 2 on a $\mathrm{T}_{2}$-weighted image (fig. 1a). Laboratory studies showed no immunosuppression or autoantibody. The initial routine CSF studies showed lymphocytic pleocytosis (156 cells/ $\mu \mathrm{l})$, elevated proteins $(155 \mathrm{mg} / \mathrm{dl})$ and a negative result for bacterial culture (table 3). EIA values for IgG antibodies was positive against VZV, HSV-1 and CMV in both serum and CSF (table 3). The EIA value for IgM antibody was only positive against VZV in serum, but negative against all three viruses in CSF (table 3). The IgG antibody index was elevated against VZV (3.28) and HSV-1 (2.25), which suggested intrathecal synthesis of IgG antibodies (table 3). In a CSF specimen collected on admission, no VZV DNA was detected by the conventional commercial single-PCR assay (table 3), but our original nested PCR assay revealed a clear positive result for the same CSF specimen (table 3 and fig. 1d). Based on these findings, the patient was diagnosed with VZV myelitis and immediately treated with acyclovir at $10 \mathrm{mg} / \mathrm{kg}$ intravenously three times a day 
Takahashi et al.: Varicella Zoster Virus Myelitis in Two Elderly Patients

for 2 weeks and methylprednisolone at $500 \mathrm{mg}$ intravenously daily for 3 days, parallel to rehabilitation. The treatment and rehabilitation succeeded and her symptoms and routine CSF findings gradually improved. The results of nested PCR assay for CSF specimens rapidly changed from positive to negative 1 week after starting treatment, whereas the IgG EIA value and IgG antibody index for VZV were continually elevated throughout the course of clinical treatment (table 3). Although numbness in the distal part of both lower limbs remained as a sequela, the patient recovered until she could walk without any assistance. She was discharged on May 10, 2010.

\section{Patient 2}

On April 5, 2011, an HIV-negative 73-year-old man developed right-chest dorsal zoster rash and was started on treatment with valacyclovir at $1 \mathrm{~g}$ orally three times a day. Despite this treatment, he developed severe anorexia, gait disturbance (on April 10) and urinary retention (on April 12), one after the other. On admission, on April 13, he was afebrile $\left(36.8^{\circ} \mathrm{C}\right)$ and focal zoster rash was distributed in the dorsal Th 5-8 region. On neurological examination, he demonstrated moderate right flaccid leg weakness with hyporeflexia, slight right Babinsky sign and severe difficulty in urinating, but no sensory disturbance. Except for a surgical operation for gastric cancer at the age of 60 , his medical and familial histories were unremarkable. Spinal cord MRI showed a high-signal-intensity lesion at Th 3-4 on a $\mathrm{T}_{2}$ weighted image (fig. 1b and c). Laboratory studies showed no immunosuppression or autoantibody. The initial routine CSF studies showed lymphocytic pleocytosis (110 cells/ $\mu$ l), elevated proteins $(93 \mathrm{mg} / \mathrm{dl})$ and a negative result of bacterial culture (table 3 ). The EIA value for IgG antibody was positive for VZV, HSV-1 and CMV in both serum and CSF (table 3). Meanwhile, the EIA value for IgM antibody was negative against all three viruses in both serum and CSF (table 3). The IgG antibody index was elevated against VZV (8.24), HSV-1 (7.30) and CMV (5.15), which suggested intrathecal synthesis of IgG antibodies (table 3). In the CSF specimen collected on admission, no VZV DNA was detected by conventional commercial single-PCR assay (table 3), but our original nested PCR assay revealed a definite positive result (table 3 and fig. 1e). Based on these findings, he was diagnosed with VZV myelitis and radiculopathy and immediately treated with acyclovir at $10 \mathrm{mg} / \mathrm{kg}$ intravenously three times a day for 2 weeks and methylprednisolone at 1,000 $\mathrm{mg}$ intravenously daily for 3 days, and then dexamethasone at $10 \mathrm{mg}$ intravenously (daily), tapering off by $2 \mathrm{mg}$ every 4 days, parallel to rehabilitation. The treatment and rehabilitation succeeded, and his symptoms and routine CSF findings gradually improved. The results of nested PCR assay for CSF specimens rapidly changed from positive to negative 1 week after the start of treatment, whereas the IgG EIA value and the IgG antibody index for VZV were continually elevated throughout the course of clinical treatment (table 3). Although severe anorexia remained as a sequela, his urinary retention was completely improved, and he recovered until he could walk with a walker. He was discharged to a rehabilitation hospital on May 26, 2011.

\section{Discussion}

This report describes 2 rare cases of elderly patients with VZV myelitis secondary to dermatomal zoster rash. In previous studies, VZV myelitis is described as frequently occurring in immunocompromised patients without dermatomal rash, whereas the disease is rare in immunocompetent patients, who usually present with rash [1-5]. The 2 patients were probably at least transiently in an age-related immunodeficient state at disease onset. 
The isolation or detection of VZV from a CSF specimen is yet rare and difficult in cases of VZV infection of the CNS, owing to the poor yield of VZV in the CSF [3-9]. In addition, virus presence closely depends on the timing of the CSF collection during the clinical course of CNS viral infection [4, 7-9]. The choice of timing to collect CSF is very difficult because VZV infection in the CNS has various clinical courses: acute, subacute or chronic [4]. In CSF specimens previously collected at the acute phase within the first 7-10 days after the onset of rash, the rate of VZV DNA detection by conventional single PCR assay was reported to be 61-76\% [7-9], and that of anti-VZV IgG antibody elevation by EIA was 0-43\% [7-9]. In contrast, at the subacute phase more than 1 week after onset, the rate for single PCR assay was $25-47 \%$ [7-9], but that of anti-VZV IgG antibody elevation was $83-100 \%$ [7-9]. Moreover, at the chronic phase more than 20 days after onset, the former was $0 \%$ and the latter was $100 \%$ [7-9]. Thus, the rate of a PCR-positive result for VZV DNA in the CSF tends to decline rapidly within 7-10 days after the onset of rash, whereas the rate of anti-VZV IgG antibody elevation tends to increase and then be maintained during the clinical course [7-9].

In this study, although the conventional single PCR assay outsourced to a commercial laboratory revealed only negative results, our original nested PCR assay could detect VZV DNA in CSF specimens collected from both patients on admission. The original nested PCR assay is regarded as much more sensitive than the conventional commercial single-step PCR assay. In previous studies, owing to the high performance of two consecutive PCR amplification steps, it was reported that the nested PCR assay technique had a 1,000 to 10,000 times higher sensitivity than the conventional single-step PCR assay [12, 13, 15]. In addition, the difference of extraction and purification methods of DNA from CSF specimens may have affected the sensitivity of the PCR assays. In our nested PCR assay, a high-molecular-weight carrier (Ethachinmate) was used as a coprecipitating agent together with the conventional phenol-chloroform extraction and ethanol precipitation [12, 13], making it possible to extract a small amount of VZV DNA from the CSF specimen more effectively than the popular column extraction kits used in the commercial single-PCR assay. However, it was considered that the collection, storage and transfer procedures of CSF specimens hardly affected the PCR assay results. Thus, the nested PCR assay is a useful assay technique with superior sensitivity and specificity. At present, regrettably, the nested PCR assay technique is not widely used in routine clinical examination, and its practical availability is only limited. It may be that the two consecutive amplification steps of the nested PCR assay are regarded as a complicated and laborious procedure. Moreover, the running cost per use of the nested PCR assay technique is not so high (approx. 50-100 USD), but there is a crucial problem in that a large expense (more than 10,000 USD) is needed to set up an appropriate laboratory infrastructure to perform this sophisticated assay technique. However, because of the demonstration of the capacity of the nested PCR assay in the diagnosis of difficult cases, in which other conventional assay methods cannot detect VZV DNA, it is speculated that, if this assay technique were widely and appropriately used within clinical practice, it would be a powerful tool for the rapid and accurate diagnosis of VZV CNS infection. It is considered important that, through translational research such as the present study, connecting clinical practice and basic laboratory research, the widespread use of the nested PCR assay technique is promoted.

For the CSF specimens collected throughout the course of clinical treatment of both patients, the nested PCR assay revealed only negative results. In contrast, the IgG EIA value and the IgG antibody index for VZV exhibited continuous elevation. Although elevations of the IgG EIA value and the IgG antibody index for HSV-1 and CMV were also shown in both patients, these findings were regarded as a cross-reaction between antibodies because these three viruses belong to Herpesviridae, a large DNA virus family. Moreover, HSV-1 and CMV 
DNA were never detected by any PCR assays for all CSF specimens; therefore, these negative results also strongly support our view. At present, whether the etiology of VZV myelitis is directly and exclusively viral, secondly immunopathological or both is still unknown [1-8]. In previous studies, pathological and virological analyses of progressive fetal VZV myelitis revealed that the disease is caused by direct viral invasion of the spinal cord [1-5]. However, the continuous elevation of intrathecal anti-VZV antibody after rapid conversion of nested PCR assay results suggests that, despite the eradication of VZV, a strong host immune response persists in CNS against VZV. Therefore, it is speculated that both the direct VZV invasion to the spinal cord as a trigger and the continuous excessive immune response in the host were closely related to the etiology of these 2 myelitis cases. The treatment with combined high-dose acyclovir and corticosteroid, for example, methylprednisolone, in these 2 patients was appropriate and effective for improvement of their functional outcomes.

Consequently, the detection of VZV DNA in CSF specimens by nested PCR assay and evaluation of the intrathecal synthesis of anti-VZV IgG antibody had significant and superior diagnostic value. We would like to emphasize the importance of rapid and precise diagnosis and adequate initial treatment in patients with VZV myelitis; the nested PCR assay and the antibody index to VZV are useful and powerful diagnostic tools in clinical practice.

\section{Acknowledgement}

We are grateful to the patients for the permission to publish this information.

\section{Disclosure Statement}

The authors declare that they have no competing interests. There are no financial conflicts of interest in this study.

\section{References}

1 Gilden DH, Beinlich BR, Rubinstien EM, Stommel E, Swenson R, Rubinstein D, Mahalingam R: Varicellazoster virus myelitis: an expanding spectrum. Neurology 1994;44:1818-1823.

2 Gupta SK, Helal BH, Kiely P: The prognosis in zoster paralysis. J Bone Joint Surg Br 1969;51:593-603.

3 de Silva SM, Mark AS, Gilden DH, Mahalingam R, Balish M, Sandbrink F, Houff S: Zoster myelitis: improvement with antiviral therapy in two cases. Neurology 1996;47:929-931.

4 Gilden DH, Bennett JL, Kleinschmidt-DeMasters BK, Song DD, Yee AS, Steiner I: The value of cerebrospinal fluid antiviral antibody in the diagnosis of neurologic disease produced by varicella zoster virus. J Neurol Sci 1998;159:140-144.

-5 Tavazzi E, Minoli L, Ferrante P, Scagnelli P, Del Bue S, Romani A, Ravaglia S, Marchioni E: Varicella zoster virus meningo-encephalo-myelitis in an immunocompetent patient. Neurol Sci 2008;29:279-283.

6 Haug A, Mahalingam R, Cohrs RJ, Schmid DS, Corboy JR, Gilden D: Recurrent polymorphonuclear pleocytosis with increased red blood cells caused by varicella zoster virus infection of the central nervous system: case report and review of the literature. J Neurol Sci 2010;292:85-88.

7 Inukai A, Katayama T, Kenjo M, Yokokawa Y, Aiba I, Saito Y: A patient with myelitis of varicella-zoster without skin lesions-diagnostic value of virus antibody index in CSF (in Japanese). Rinsho Shinkeigaku 2010;50:634-640.

-8 Echevarría JM, Casas I, Tenorio A, de Ory F and Martínez-Martín P: Detection of varicella-zoster virusspecific DNA sequences in cerebrospinal fluid from patients with acute aseptic meningitis and no cutaneous lesions. J Med Virol 1994;43:331-335.

9 Gregoire SM, van Pesch V, Goffette S, Peeters A, Sindic CJ: Polymerase chain reaction analysis and oligoclonal antibody in the cerebrospinal fluid from 34 patients with varicella-zoster virus infection of the nervous system. J Neurol Neurosurg Psychiatry 2006;77:938-942. 
10 Takasu T, Mgone JM, Mgone CS, Miki K, Komase K, Namae H, Saito Y, Kokubun Y, Nishimura T, Kawanishi R, Mizutani T, Markus TJ, Kono J, Asuo PG, Alpers MP: A continuing high incidence of subacute sclerosing panencephalitis (SSPE) in the Eastern Highlands of Papua New Guinea. Epidemiol Infect 2003;131:887-898

11 Reiber H, Lange P: Quantification of virus-specific antibodies in cerebrospinal fluid and serum: sensitive and specific detection of antibody synthesis in brain. Clin Chem 1991;37:1153-1160.

12 Takahashi T, Nakayama T, Tamura M, Ogawa K, Tsuda H, Morita A, Hara M, Togo M, Shiota H, Suzuki Y, Minami M, Ishikawa H, Miki K, Shikata E, Takahashi S, Kuragano T, Matsumoto K, Sawada S, Mizutani T: Nested polymerase chain reaction for assessing the clinical course of tuberculous meningitis. Neurology 2005;64:1789-1793.

13 Takahashi T, Tamura M, Asami Y, Kitamura E, Saito K, Suzuki T, Takahashi SN, Matsumoto K, Sawada S, Yokoyama E, Takasu T: Novel 'wide range' quantitative nested real-time PCR assay for Mycobacterium tuberculosis DNA: development and methodology. J Clin Microbiol 2008;46:1708-1715.

14 Franzen-Röhl E, Tiveljung-Lindell A, Grillner L, Aurelius E: Increased detection rate in diagnosis of herpes simplex virus type 2 meningitis by real-time PCR using cerebrospinal fluid samples. J Clin Microbiol 2007;45:2516-2520.

15 Liu PY, Shi ZY, Lau YJ, Hu BS: Rapid diagnosis of tuberculous meningitis by a simplified nested amplification protocol. Neurology 1994;44:1161-1164.

Table 1. Sequences of primers for original nested PCR assay

\begin{tabular}{|c|c|c|c|c|c|c|}
\hline Target & Assay & Type & & Sequence & $\begin{array}{l}\text { Nucleotide } \\
\text { position }\end{array}$ & $\begin{array}{l}\text { Product } \\
\text { size }\end{array}$ \\
\hline \multirow{2}{*}{$\begin{array}{l}\text { ORF-29 of } \\
\text { wild VZV } \\
\text { DNA }^{1}\end{array}$} & $\begin{array}{l}\text { First-step PCR } \\
\text { (=single PCR) }\end{array}$ & $\begin{array}{l}\text { outer forward primer } \\
\text { outer reverse primer }\end{array}$ & $\begin{array}{l}\text { WZ-F1 } \\
\text { WZ-R1 }\end{array}$ & $\begin{array}{l}\text { 5'-GTCCTAGAGGAGGTTTTATCTGC-3' } \\
5^{\prime} \text {-AATGCCATATGTTGTGCTCGAGC-3' }\end{array}$ & $\begin{array}{l}53942-53964 \\
54113-54091\end{array}$ & 172 \\
\hline & $\begin{array}{l}\text { Second-step PCR } \\
\text { (=nested PCR) }\end{array}$ & $\begin{array}{l}\text { inner forward primer } \\
\text { inner reverse primer }\end{array}$ & $\begin{array}{l}\text { WZ-F2 } \\
\text { WZ-R2 }\end{array}$ & $\begin{array}{l}5^{\prime} \text {-TCCCTCGTCGGGAAATCGAGAAA-3' } \\
5^{\prime} \text {-TATGGCTAATTGAACCATGGCCC-3' }\end{array}$ & $\begin{array}{l}53976-53998 \\
54063-54041\end{array}$ & 88 \\
\hline
\end{tabular}

GenBank accession no. ${ }^{1}$ NC_001348.1 (X04370).

Table 2. Original nested PCR assay conditions

\begin{tabular}{llll}
\hline First-step PCR & \multicolumn{3}{l}{ Second-step PCR } \\
\hline Initial denaturing & $96.0^{\circ} \mathrm{C}: 3 \mathrm{~min}$ & Initial denaturing & $96.0^{\circ} \mathrm{C}: 3 \mathrm{~min}$ \\
Amplification & $35 \mathrm{cycles}$ & Amplification & $25 \mathrm{cycles}$ \\
Denaturing & $95.0^{\circ} \mathrm{C}: 30 \mathrm{~s}$ & Denaturing & $94.0^{\circ} \mathrm{C}: 30 \mathrm{~s}$ \\
Annealing & $60.0^{\circ} \mathrm{C}: 30 \mathrm{~s}$ & Annealing & $55.0^{\circ} \mathrm{C}: 30 \mathrm{~s}$ \\
Extension & $72.0^{\circ} \mathrm{C}: 1 \mathrm{~min}$ & Extension & $72.0^{\circ} \mathrm{C}: 1 \mathrm{~min}$ \\
Final extension & $72.0^{\circ} \mathrm{C}: 10 \mathrm{~min}$ & Final extension & $72.0^{\circ} \mathrm{C}: 10 \mathrm{~min}$ \\
\hline
\end{tabular}


Takahashi et al.: Varicella Zoster Virus Myelitis in Two Elderly Patients

Table 3. Summary of clinical study results in 2 patients during clinical course

\begin{tabular}{|c|c|c|c|c|c|c|c|}
\hline Patient 1 & $\begin{array}{l}\text { CSF collection } \\
\text { date }\end{array}$ & $\begin{array}{l}\text { March 11, } 2010 \\
\text { (on admission) }\end{array}$ & March 18 & March 25 & April 5 & April 20 & May 7 \\
\hline \multirow[t]{8}{*}{ Basal CSF findings } & $\mathrm{RBC}, / \mu \mathrm{l}$ & 2 & 1 & 0 & 1 & 0 & 0 \\
\hline & Cell (WBC), $/ \mu \mathrm{l}$ & 156 & 113 & 105 & 50 & 25 & 8 \\
\hline & $\mathrm{M}: \mathrm{P}$ & $460: 9$ & $330: 8$ & $310: 4$ & $147: 2$ & $35: 2$ & $23: 5$ \\
\hline & Protein, mg/dl & 155 & 138 & 107 & 70 & 56 & 48 \\
\hline & Glucose, mg/dl & 51 & 50 & 61 & 61 & 48 & 52 \\
\hline & Bacterial culture & - & - & - & - & - & - \\
\hline & CSF IgG, mg/dl & 34.0 & 13.5 & 19.1 & 25.4 & 22.9 & N.D. \\
\hline & Serum IgG, mg/dl & 1,115 & 1,143 & 972 & 684 & 783 & N.D. \\
\hline Commercial single- & VZV DNA & - & - & - & - & - & N.D. \\
\hline PCR assays & HSV1 DNA & - & - & - & N.D. & N.D. & N.D. \\
\hline (SRL Inc.) & CMV DNA & - & - & N.D. & N.D. & N.D. & N.D. \\
\hline $\begin{array}{l}\text { Original nested PCR } \\
\text { assay }\end{array}$ & VZV DNA & + & - & - & - & - & N.D. \\
\hline IgM EIA value & Anti-VZV & & & & & & \\
\hline (negative $<0.8$ & CSF & 0.51 & 0.18 & 0.11 & 0.09 & N.D. & N.D. \\
\hline \multirow[t]{7}{*}{ positive >1.2) } & Serum & $1.26^{*}$ & 0.78 & 0.82 & 0.74 & N.D. & N.D. \\
\hline & Anti-HSV1 & & & & & & \\
\hline & CSF & 0.62 & 0.28 & 0.18 & N.D. & N.D. & N.D. \\
\hline & Serum & 0.71 & 0.76 & 0.68 & N.D. & N.D. & N.D. \\
\hline & Anti-CMV & & & & & & \\
\hline & CSF & 0.44 & 0.16 & N.D. & N.D. & N.D. & N.D. \\
\hline & Serum & 0.34 & 0.24 & N.D. & N.D. & N.D. & N.D. \\
\hline IgG EIA value & Anti-VZV & & & & & & \\
\hline (CSF: negative $<0.20$ & CSF & $>12.8^{*}$ & $>12.8^{*}$ & $11.6^{*}$ & $8.73^{*}$ & $7.48^{*}$ & N.D. \\
\hline positive $>0.40$ & Serum & $>128.0^{*}$ & $>128.0^{*}$ & $105.2^{*}$ & $75.4^{*}$ & $66.3^{*}$ & N.D. \\
\hline \multirow[t]{8}{*}{$\begin{array}{l}\text { Serum: negative }<2.0 \\
\text { positive }>4.0 \text { ) }\end{array}$} & $\begin{array}{l}\text { Antibody index } \\
\text { Anti-HSV1 }\end{array}$ & $3.28^{\dagger}$ & $8.47^{\dagger}$ & $5.62^{\dagger}$ & $3.12^{\dagger}$ & $3.86^{\dagger}$ & N.D. \\
\hline & CSF & $8.8^{*}$ & $7.8^{*}$ & $6.8^{*}$ & $3.5^{*}$ & N.D. & N.D. \\
\hline & Serum & $>128.0^{*}$ & $125.4^{*}$ & $98.7^{*}$ & $68.3^{*}$ & N.D. & N.D. \\
\hline & Antibody index & $3.28^{\dagger}$ & $5.27^{\dagger}$ & $3.51^{\dagger}$ & 1.37 & N.D. & N.D. \\
\hline & Anti-CMV & & & & & & \\
\hline & CSF & $2.5^{*}$ & $2.0^{*}$ & $0.8^{*}$ & N.D. & N.D. & N.D. \\
\hline & Serum & $84.5^{*}$ & $85.4^{*}$ & $52.6^{*}$ & N.D. & N.D. & N.D. \\
\hline & Antibody index & 0.97 & 1.98 & 0.77 & N.D. & N.D. & N.D. \\
\hline Patient 2 & CSF collection date & $\begin{array}{l}\text { April 13, } 2011 \\
\text { (On admission) }\end{array}$ & April 20 & April 27 & May 11 & May 20 & \\
\hline \multirow[t]{8}{*}{ Basal CSF findings } & $\mathrm{RBC}, / \mu \mathrm{l}$ & 0 & 2 & 1 & 0 & 1 & \\
\hline & Cell (WBC), $/ \mu \mathrm{l}$ & 110 & 20 & 10 & 4 & 3 & \\
\hline & $\mathrm{M}: \mathrm{P}$ & $320: 11$ & $30: 1$ & $16: 1$ & $9: 1$ & $11: 2$ & \\
\hline & Protein, mg/dl & 93 & 61 & 29 & 33 & 24 & \\
\hline & Glucose, mg/dl & 51 & 61 & 62 & 58 & 54 & \\
\hline & Bacterial culture & - & - & - & - & - & \\
\hline & CSF IgG, mg/dl & 22.5 & 9.0 & 5.1 & 6.2 & N.D. & \\
\hline & Serum IgG, mg/dl & 1,855 & 1,603 & 1,268 & 1,044 & N.D. & \\
\hline Commercial single- & VZV-DNA & - & - & - & - & N.D. & \\
\hline PCR assays & HSV1-DNA & - & - & - & N.D. & N.D. & \\
\hline
\end{tabular}


Takahashi et al.: Varicella Zoster Virus Myelitis in Two Elderly Patients

\begin{tabular}{|c|c|c|c|c|c|c|}
\hline (SRL Inc.) & CMV-DNA & - & - & N.D. & N.D. & N.D. \\
\hline $\begin{array}{l}\text { Original nested PCR } \\
\text { assay }\end{array}$ & VZV-DNA & + & - & - & - & N.D. \\
\hline IgM EIA value & Anti-VZV & & & & & \\
\hline (negative $<0.8$ & CSF & 0.24 & 0.15 & 0.09 & 0.11 & N.D. \\
\hline \multirow[t]{7}{*}{ positive >1.2) } & Serum & 0.18 & 0.16 & 0.15 & 0.16 & N.D. \\
\hline & Anti-HSV1 & & & & & \\
\hline & CSF & 0.30 & 0.31 & 0.60 & N.D. & N.D. \\
\hline & Serum & 0.46 & 0.50 & 0.57 & N.D. & N.D. \\
\hline & Anti-CMV & & & & & \\
\hline & CSF & 0.20 & 0.22 & N.D. & N.D. & N.D. \\
\hline & Serum & 0.37 & 0.38 & N.D. & N.D. & N.D. \\
\hline IgG EIA value & Anti-VZV & & & & & \\
\hline (CSF: negative $<0.20$ & CSF & $>12.8^{*}$ & $>12.8^{*}$ & $10.3^{*}$ & $7.8^{*}$ & N.D. \\
\hline positive $>0.40$ & Serum & $>128^{*}$ & $124.2^{*}$ & $115.7 *$ & $85.8^{*}$ & N.D. \\
\hline \multirow{9}{*}{$\begin{array}{l}\text { Serum: negative }<2.0 \\
\text { positive }>4.0 \text { ) }\end{array}$} & Antibody index & $8.24^{\dagger}$ & $18.35^{\dagger}$ & $22.13^{\dagger}$ & $12.67^{\dagger}$ & N.D. \\
\hline & Anti-HSV1 & & & & & \\
\hline & CSF & $7.3^{*}$ & $6.3^{*}$ & $8.3^{*}$ & $6.8^{*}$ & N.D. \\
\hline & Serum & $>128^{*}$ & $99.6^{*}$ & $>128^{*}$ & $105.4^{*}$ & N.D. \\
\hline & Antibody index & $4.70^{\dagger}$ & $11.26^{\dagger}$ & $16.12^{\dagger}$ & $10.8^{\dagger}$ & N.D. \\
\hline & Anti-CMV & & & & & \\
\hline & CSF & $2.0^{*}$ & $2.0^{*}$ & N.D. & N.D. & N.D. \\
\hline & Serum & $32 *$ & $18.2^{*}$ & N.D. & N.D. & N.D. \\
\hline & Antibody index & $5.15^{\dagger}$ & $19.57^{\dagger}$ & N.D. & N.D. & N.D. \\
\hline
\end{tabular}

$\mathrm{M}=$ Mononuclear cell; $\mathrm{P}=$ polymorphonuclear cell; N.D. = not done. ${ }^{*}$ positive EIA value; ${ }^{\dagger}$ positive antibody index. 

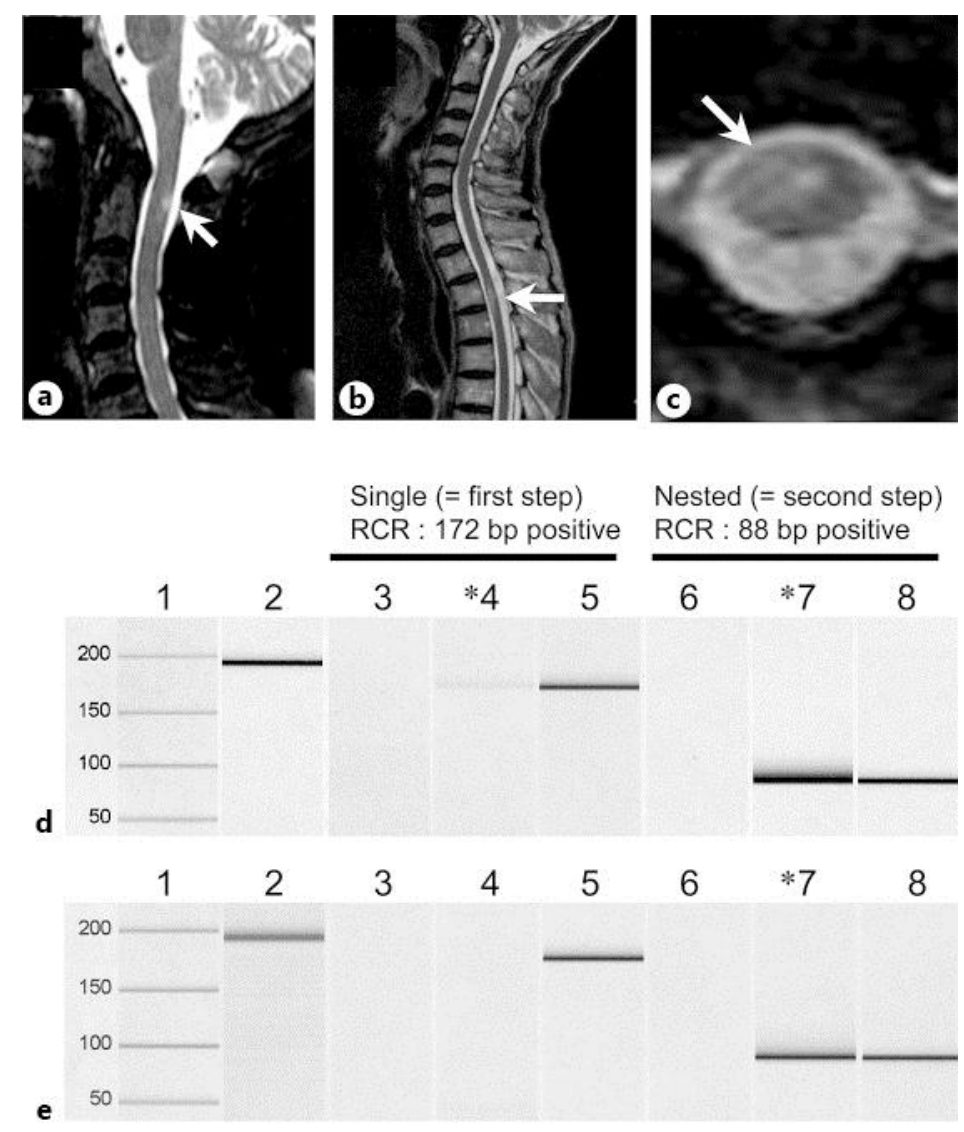

Fig. 1. a-c Spinal cord MRI findings. a Sagittal T2-weighted MRI (TR 3809, TE110) of the cervical spine (c) in patient 1. A high-signal-intensity lesion at the cervical spinal nerve 2 is shown. $\mathbf{b}$ Sagittal $\mathrm{T}_{2}$-weighted MRI (TR 3797, TE 110) of thoracic spine in patient 2. c Axial T2-weighted MRI (TR 539, TE 18) of thoracic spine in patient 2. A high-signal-intensity lesion at Th 3-4 is shown. d, e Nested PCR assay results for the CSF specimen collected on admission. $\mathbf{d}$ Patient 1 , e patient $2 .{ }^{*}$ Positive result. Lane 1: molecular weight marker, lane 2: internal control (human $\beta$-globin: $196 \mathrm{bp}$ ), lane 3: negative control (clinically isolated Staphylococcus aureus DNA), lane 4: case, lane 5: positive control (172 bp), lane 6: negative control, lane 7: case, lane 8: positive control ( $88 \mathrm{bp}$ ), lanes 3-5: single-PCR assay results, lanes 6-8: nested PCR results. As a positive control, the original plasmid into which a DNA fragment (172 bp) of the ORF-29 gene had been inserted was prepared. The nucleotide sequence of the inserted DNA fragment was confirmed by direct sequencing in both strands. The extracted DNA specimens from clinically isolated Staphylococcus aureus were used as a negative control. In addition, as an internal control, a pair of primers specific to the human $\beta$-globin gene (GenBank accession no. L48217) was prepared. The 196-bp human $\beta$-globin gene fragment as an internal control was amplified in another tube under the same assay conditions. In conventional single-PCR assay, a weak 172-bp band was only shown at lane 4 for patient 1 . In contrast, the nested PCR assay demonstrated clearly positive 88 -bp bands at lane 7 for both patients. 